\title{
The Impact of Pesticides on Tarnave Vineyard Biodiversity Ecosystem
}

\author{
Liliana TOMOIAGĂ \\ Reasearch Station for Viticulture and Enology Blaj, 2 Gh. Baritiu Street, 515400, Blaj, Romania; \\ ${ }^{*}$ Corresponding author, e-mail: tomoiagaliliana@yahoo.com
}

Bulletin UASVM Horticulture 72(1) / 2015

Print ISSN 1843-5254, Electronic ISSN 1843-5394

Doi:10.15835/buasvmcn-hort:10702

\begin{abstract}
The research focused on evaluating biodiversity of useful and harmful fauna depending on the technology used in controlling plant pests and diseases of the vine. By analyzing the ecological indicators values: analytical index (abundance, constancy, dominance) and synthetic index (ecological significance index), was established the contribution of each species in natural biological control of eriofizi mites population.
\end{abstract}

Keywords: biodiversity, useful and harmful species, viticulture ecosystem.

\section{INTRODUCTION}

On vine plantations from Târnave vineyard the impact of technological factors, especially pesticide treatments (Comăniță et al., 1986), induced significant changes in the structure and abundance of useful and harmful biodiversity species. To protect biodiversity, the modern programs are growing increasingly and they are based on more limited use of chemical treatments (Tomoiagă, 2001).

\section{AIMS}

The purpose of the research was to establish the optimal variant of the risk reduction without reducing significantly the production and quality in conditions of biodiversity conservation and restoration of biological equilibrium predator/ pest.

The experiments had the following directions: testing of new entomotoxice and fungicide active substances whit highly effective and which presents a low environmental and useful entomofauna impact: bentonite (wettable powder) potassium phosphate $\left(\mathrm{K}_{2} \mathrm{HPO}_{3}\right)$ sodium bicarbonate, potassium bicarbonate, ammonium bicarbonate, sodium silicate, Trichoderma harzianum and minimizing the use of inputs through use of mixed action products and mixtures of pesticides depending on the possibilities of complexation on the basis of: kresoxim metil, trifloxistrobin and tebuconazol, trifloxistrobin and cimoxanil, azoxistrobin and folpet, azoxistrobin, triadimenol and folpet, sulf.

\section{MATERIALS AND METHODS}

The research was conducted in 2010-2012 in the experimental lots of SCDVV Blaj planted with 'Fetească regală', variety representative for Târnave vineyard. The research focused on evaluating biodiversity of useful and harmful fauna depending on the technology used in controlling plant pests and diseases of the vine. Experimental variants studied were: V1 - organic variant which is applied unconventional technology based on the use of pesticides with low ecological risk; V2 - conventional variant based on the use of latest generation chemical pesticides; V3 - variant untreated control. By analyzing the ecological indicators values: ecological significance index (abundance, constancy, dominance), was established the contribution of each species in natural biological control of eriofizi mites population. Abundance represents the absolute number of individuals of a species present in an area. The dominance relation is shown in which a given species flock to the amount of individuals who associate with other species expressing the relative abundance background. Constance expresses the continuity of the emergence of a given species habitat. This feature shows how 
Tab.1. Abundance (A), dominance (D), constancy (C) and ecological significance index (W) at acarifage species from Târnave Vineyard plantations .

\begin{tabular}{|c|c|c|c|c|c|c|c|c|c|c|c|c|}
\hline \multirow{2}{*}{ Taxoni } & \multicolumn{4}{|c|}{ Organic (V 1) } & \multicolumn{4}{|c|}{ Conventional (V 2) } & \multicolumn{4}{|c|}{ Untreated control (V 3) } \\
\hline & $\mathrm{A}$ & $\mathrm{D}$ & $\mathrm{C}$ & $\mathrm{W}$ & $\mathrm{A}$ & $\mathrm{D}$ & $\mathrm{C}$ & $\mathrm{W}$ & $\mathrm{A}$ & $\mathrm{D}$ & $\mathrm{C}$ & $\mathrm{W}$ \\
\hline Typhlodromus pyrii & 20 & 19.8 & 75 & 14.9 & 4 & 6.9 & 75 & 5.2 & 19 & 16.4 & 75 & 12.3 \\
\hline Phytoseiulus persimilis & 18 & 17.8 & 100 & 17.8 & 6 & 10.2 & 75 & 7.7 & 15 & 12.9 & 100 & 12.9 \\
\hline Crysopa carnea & 4 & 4.0 & 75 & 3.0 & 8 & 13.8 & 100 & 13.8 & 13 & 11.2 & 75 & 8.4 \\
\hline Aeolothrips intermedius & 2 & 2.0 & 25 & 0.5 & 2 & 3.4 & 25 & 0.9 & 1 & 0.9 & 25 & 0.2 \\
\hline Stethorus punctillum & 11 & 10.9 & 50 & 5.4 & 6 & 10.3 & 75 & 7.8 & 1 & 0.9 & 50 & 0.4 \\
\hline Antochorus nemorum & 1 & 1.0 & 75 & 0.7 & 1 & 1.7 & 25 & 0.4 & 1 & 0.9 & 75 & 0.6 \\
\hline Coccinella 7-punctata & 4 & 4.0 & 100 & 4.0 & 12 & 20.7 & 100 & 20.7 & 10 & 8.6 & 100 & 8.6 \\
\hline Amblyseius aberrans & 1 & 1.0 & 75 & 0.7 & 1 & 1.7 & 25 & 0.4 & 3 & 2.6 & 75 & 1.9 \\
\hline Orius niger & 4 & 4.0 & 75 & 3.0 & - & - & - & - & 13 & 11.2 & 75 & 8.4 \\
\hline Adalia bipunctata & 9 & 8.9 & 50 & 4.5 & - & - & - & - & 9 & 7.8 & 50 & 3.9 \\
\hline Forficula auricularia & 6 & 5.9 & 100 & 5.9 & 8 & 13.8 & 75 & 10.4 & 2 & 1.7 & 100 & 1.7 \\
\hline Crysopa formosa & 4 & 4.0 & 75 & 3.0 & 2 & 3.4 & 75 & 2.6 & 1 & 0.9 & 75 & 0.6 \\
\hline Coccinella 14-punctata & 1 & 1.0 & 100 & 1.0 & 3 & 5.2 & 75 & 3.9 & 13 & 11.2 & 100 & 11.2 \\
\hline Adalia variegata & 2 & 2.0 & 20 & 0.4 & 1 & 1.7 & 25 & 0.4 & 1 & 0.9 & 20 & 0.2 \\
\hline Oligota flaviventis & 3 & 3.0 & 25 & 0.7 & - & - & - & - & 2 & 1.7 & 25 & 0.4 \\
\hline Orius vicinus & 7 & 6.9 & 50 & 3.5 & - & - & - & - & 9 & 7.8 & 50 & 3.9 \\
\hline Orius majusculus & 2 & 2.0 & 25 & 0.5 & - & - & - & - & 1 & 0.9 & 25 & 0.2 \\
\hline Carabus auratus & 1 & 1.0 & 50 & 0.5 & 4 & 6.6 & 75 & 5.0 & 1 & 0.9 & 50 & 0.4 \\
\hline Calosoma sp. & 1 & 1.0 & 25 & 0.2 & - & - & - & - & 1 & 0.9 & 25 & 0.2 \\
\hline Total & 101 & & & & 58 & & & & 116 & & & \\
\hline
\end{tabular}

some species participating in the biocenosis structure (Simionescu, 1983).

\section{RESULTS AND DISCUSSION}

The results showed significant differences regarding biodiversity of useful and harmful fauna in relation to the active substance and history of treatments applied. In the organic variant was identified 19 species, of which the largest dominant were recorded of species from orders: Acari (38\%), Neuroptera (8\%), Thysanoptera (2\%), Coleoptera (29\%) Heteroptera (17\%), Dermaptera (6\%). Dominance index value has highlighted four dominant species: Typhlodromus pyri, Phytoseiulus persimilis, Stethorus punctillum, Adalia bipunctata, and subdominant species: Antochorus nemorum, Coccinella 7-punctata Amblyseius aberrans, Orius niger, Forficula auricularia (Tab. 1).

In the conventional variant was identified 13 species, of which the largest dominant were recorded of species from orders: Coleoptera (45\%), Acari (19\%), Neuroptera (17\%) Dermaptera (14\%) Thysanoptera (4\%), Heteroptera (2\%). Dominance index value has highlighted dominant species: Coccinella 7-punctata, Phytoseiulus persimilis, Crysopa carnea, Typhlodromus pyrii, Stethorus punctillum, Forficula auricularia and subdominant species: Aeolothrips intermedius,
Adalia variegata Carabus auratus. Organic index values vary depending on the abiotic conditions of tested variants.

\section{CONCLUSION}

- The principal means of protecting the natural level entomophagus against harmful organisms is based on eliminating aggressive chemical methods of combating and promotion of biological control methods.

- In organic variant the dominant index value highlights four dominant species of which are distinguished Acari species, represented 38\% of the species reported.

- In conventional variant, chemically treated, the dominance index showed six dominant species representing Coleoptera $45 \%$, of the species reported.

\section{REFERENCES}

1. Comăniță E, Soldea C, Dumitrescu E. (1986). Chemistry and Technology of pesticides, Ed. Tehnică, București.

2. Simionescu V, (1983). Practical work of ecology, Iaşi, A. I. Cuza 1983, p. 174 - 190.

3. Tomoiagă L, (2001). Research on useful entomofauna Tarnave acarofaga this vineyard. Analele ICDVV Valea Călugărească Vol. 16. pp. 203-211. 